\title{
THE IMPLEMENTATION OF EXTRACTION FEATURE USING GLCM AND BACK-PROPAGATION ARTIFICIAL NEURAL NETWORK TO CLASIFY LOMBOK SONGKET WOVEN CLOTH
}

\author{
Bahtiar Imran ${ }^{*}$; Muhamad Masjun Efendi² \\ Software Engineering \\ Universitas Teknologi Mataram \\ https://www.utmmataram.ac.id \\ bahtiarimranlombok@gmail.com ${ }^{1}$, creativepio@gmail.com ${ }^{2}$ \\ $\left.{ }^{*}\right)$ Corresponding Author
}

\begin{abstract}
The aimed of this study was to apply the feature extraction method of GLCM and Backpropagation Artificial Neural Network (ANN) to classify Lombok's typical Songket woven cloth by classifying based on the texture of the Songket woven cloth. Songket woven cloth in Lombok in terms of weaving and texture are vary from region to region. For example the songket woven cloth in Pringgasela Village, Sukarara Village and Sade Village has differences in texture and motifs. For this reason, this study focuses on classifying Lombok's typical Songket woven cloth by performing feature extraction on woven cloth using the GLCM method and the classification method uses Back-propagation Artificial Neural Network (ANN). For data collection, the data was taken directly from the Songket weaving centers in Pringgasela, Sade, and Sukarara. In the classification stage, the training data used were 64 data and 11 test data. Then the epoch used was 41 iterations with a time of 0:00:04, with neurons 80 and 100 . The use of neurons 80 generated $18 \%$ which was successful in the classification. While using 100 neurons generated 100\% successful which was can be classified. Based on the classification results obtained, the use of 100 neurons gained good classification results.
\end{abstract}

Keyword: GLCM, feature Extraction, backpropagation neural network

\footnotetext{
Abstrak- Tujuan dari penelitian ini adalah menerapkan metode ekstraksi fitur dari GLCM dan Jaringan Syaraf Tiruan Backpropagation untuk mengklasifikasi kain tenun songket khas Lombok, dengan cara mengklasifikasi berdasarkan tekstur pada kain tenun songket khas Lombok. Kain tenun songket di Lombok dari segi penenunan dan tekstur berbeda-beda antara daerah yang satu dengan daerah lainnya. Contohnya kain tenun songket yang ada di Desa Pringgasela, Desa Sukarara dan Desa Sade mempunyai perbedaan dari segi tekstur dan
}

motifnya, untuk itu penelitian ini fokus dalam mengklasifikasi kain tenun songket khas Lombok dengan melakukan ekstraksi fitur pada kain tenun khas Lombok menggunakan metode GLCM dan metode klasifikasinya menggunakan Jaringan Syaraf Tiruan Backpropagation. Untuk pengambilan datanya diambil lansung dari pusat tenun kain songket khas Lombok yang ada di Pringgasela, Sade dan Sukarara. Pada tahap klasifikasi data latih yang digunakan sebanyak 64 data dan 11 data uji. Kemudian epoch yang digunakan yaitu 41 iterasi dengan waktu 0:00:04, dengan neuron 80 dan 100. Penggunaan neuron 80 menghasilkan 18\% yang berhasil di klasifikasi. Sedangkan menggunakan neuron 100, mendapatkan keberhasilan 100\% yang dapat di klasifikasi. Berdasarkan hasil klasifikasi yang didapatkan, penggunaan neuron 100 mendapatkan hasil klasifikasi yang baik.

Kata Kunci: GLCM, ekstraski fitur, jaringan syaraf tiruan backpropagation.

\section{INTRODUCTION}

Indonesia has many cultural heritages that must be preserved in the form of traditional clothes, such as songket, batik, and weaving. One area that has a variety of motifs, shapes, and textures of the songket is Lombok. Lombok is not only the center of the world's attention for its natural beauty. However, the woven cloth which is produced by the societies has also become one of the centers of attention for tourists visiting Lombok. Lombok woven cloth comes from the original Sasak tribe who lived in Lombok for many years ago. So it is not surprising that the typical Lombok weaving motifs are the philosophy of the Sasak culture. Songket centers in the Lombok area such as Pringgasela, Sukarara, and Sade Village have different textures and motifs according to the characteristics of each region. Because there are various textures and motifs related to songket 
cloth, so not everyone can distinguish the regional origin of a particular songket motif due to the difficulty of defining the characteristics of the songket motif from an area and so various Songket motifs that exist and with a variety of color compositions as well (Amalia, 2018).

Songket is a type of woven cloth known throughout Indonesia. The method of weaving and Songket motifs differs from region to region. People do not know much information about Songket motifs. This is because there is no good computerized data collection (Amalia, 2018), that distinguishes various types of Songket patterns automatically can be done with the assistance of a computer (computer-aided). This is based on taking the right characteristics of the Songket, which is texture characteristics (Soesanti, 2015). Classification of an object can be done indirectly by classifying the object's image based on its features. Some of the features that can be extracted from an image are color, shape, and texture (Setiohardjo, 2013). Texture in images can also be interpreted as images with natural textures (Imran, 2019).

Many methods are used to obtain accurate feature extraction results one of them is the GLCM method. Many studies have concluded that the GLCM method is better than other feature extraction methods (Pathak, B., \& Barooah, 2013). GLCM is a statistical analysis for feature extraction in an image (Mohanaiah et al., 2013).

Various studies related to the classification of songket cloth have been carried out with various methods and objects used. Even the feature extraction of songket cloth using GLCM has been carried out using songket cloth objects from other areas by classifying the motifs of the songket cloth (Setiohardjo, 2013). Not only Indonesian songket cloth that has been objectified using the GLCM method, however, the Malay songket cloth has also been done by obtaining the GLCM results and PCM provides good recognition results (Gressiva., and Chandra, 2018). Not only textures and motifs that can be researched, but the pattern of songket cloth using the wavelet method also gets good segmentation results (Mauko, I, C., and Lukmetlabla, N, M, 2016).

Currently, the classification of songket motifs has been widely applied by various methods. In this study, the researcher tried to implement the feature extraction for the classification of Lombok songket motifs. The feature extraction method used is the Gray Level Co-occurrence Matix (GLCM) while the classification method used is the Backpropagation Neural Network, as for the features that will be used are 4 features, such as correlation, energy, homogeneity, and contrast. While the angle used is 00 , because angle 00 provides better extraction results (Imran et al., 2018). Data collection from this research is taken directly from the center of Lombok Songket cloth centers in Pringgasela, Sukarara, and Sade Village. The training data used in this study were 64 image data of Songket cloth that had been cropped according to the proposed size, $800 \times 800$ pixels. While the test data used in this study were 11 image data of Songket cloth.

\section{MATERIALS AND METHODS}

\section{A. Data Retrieval}

In this study, data collection was carried out in 3 areas of the Lombok Songket craft center. Places were used for data collection include Pringgasela District, East Lombok Regency, Sukarara Village, Jonggat District, Central Lombok Regency and Sade, Pujut District, Central Lombok Regency. From these three areas of Lombok songket craft centers, the three of them have different songket motifs and names that make the songket cloth of each region have its charm for tourists.

\section{B. Image Acquisition}

Image acquisition is carried out to classify the image data of the songket cloth that has been taken from various areas of the songket craft center. At the time the data was collected, the data was still random and the officers who carried out the data collection were also different, In this case, image acquisition is necessary. The grouping is done to facilitate the training process and testing process. Pre-processing

\section{Pre-processing}

Pre-processing is done to reduce the size of the image so that it is easier to extract the image. The initial image at the time of data collection is $3456 \times 2304$ pixels, so that from this size requires a long extraction time, therefore, in this stage, the initial image size is cropped to $800 \times 800$ pixels. This cropping step also needs to be done to find the best position of an image, because when data collection is not always at a perfect angle. In this process, the name of each songket is given in each region. This is because the names of the songket in each area of the craft center are different. Example: the songket cloth "Anteng" from Pringgasela and the songket cloth "Penginang" from Sade. Figure 1 is an example of a pre-processed songket. 


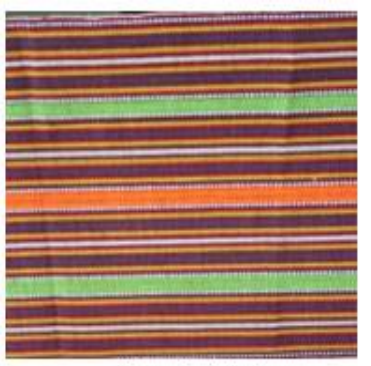

a. Songket Anteng

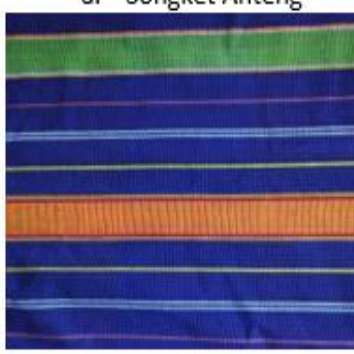

c. Songket Biru Garis

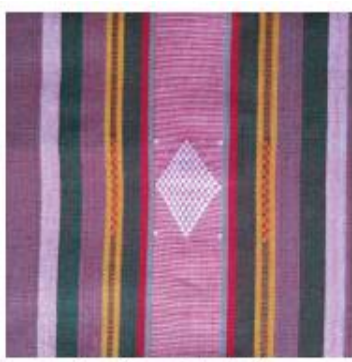

b. Songket Antik

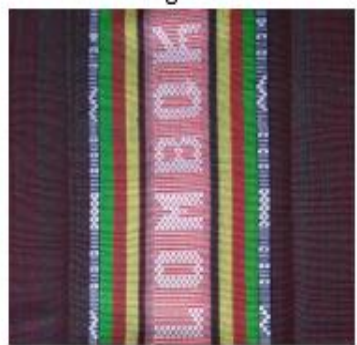

d. Songket Sempara Jarang
Source: (Imran \& Efendi, 2020)

Figure 1. Pre-processed Songket Cloth

\section{Implementation of the GLCM}

The implementation of GLCM is carried out to obtain the value of the songket feature extraction results. GLCM is a method that can provide good extraction results (Suharjito et al., 2017). GLCM is a feature extraction method that uses texture calculations in the second-order, which takes into account two pixels of the original image, in Figure 4 in the direction of co-occurrence in GLCM (Surya, R. A., Fadlil, A., \& Yudhana, 2017).

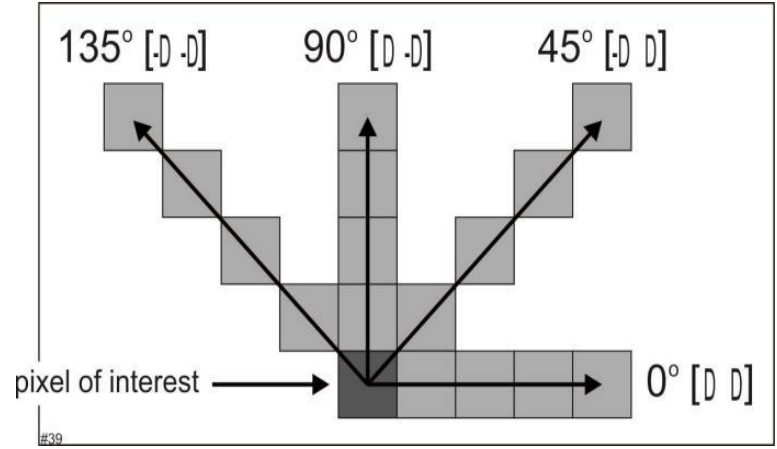

Source: (Imran \& Efendi, 2020)

Figure 2. GLCM accuracy direction

GLCM has features that are used in providing extraction on images. Some of the features that can be extracted in GLCM are Contrast, Correlation, Energy, and Homogeneity. Energy calculates the total of each element squared. Contrast calculates the local variation of the GLCM gray-level. Contrast calculates the local variation of the GLCM gray-level. Correlation calculates the probability of concurrently occurred a pair of pixels. Homogeneity shows the distance distribution of the elements in GLCM. In a texture, there is usually repeated homogeneity, so this feature is most suitable for texture classification (Sari, 2018).

In this study, the GLCM method was used to extract the texture of the songket cloth as the object of research. The features used in this study are Contrast, Correlation, Energy, and Homogeneity (Suharjito et al., 2017).

$$
\begin{array}{ll}
\text { Correlation } & \sum_{i}^{k}=1 \sum_{j}^{k}=1 \frac{\left(i-m_{r}\right)\left(j-m_{c}\right) p_{i j}}{\vartheta_{r} \delta_{c}} \\
\text { Contrast } & \sum_{i}^{k}=1 \sum_{j}^{k}=1(i-j)^{2} P_{i j} \\
\text { Homog } & \sum_{i}^{k}=1 \sum_{j}^{k}=1 P_{i j}^{2} \\
\text { entity } & \\
\text { Energy } & \sum_{i}^{k}=1 \sum_{j}^{k}=1 \frac{P_{i j}}{1+[i-j]}
\end{array}
$$

\section{E. The Implementation of Back-propagation Neural Networks}

The Implementation of Back-propagation Neural Network is used as a method in the image classification of songket cloth. Before the classification stage, songket images were extracted using the GLCM method. The classification method using the Backpropagation Artificial Neural Network is considered capable of providing a good classification of images (A. Kasim \& Harjoko, 2014)

In this study, the classification of the songket image cloth using the Back-propagation Neural Network. The implementation of the Backpropagation Neural Network can be seen in Figure 3.

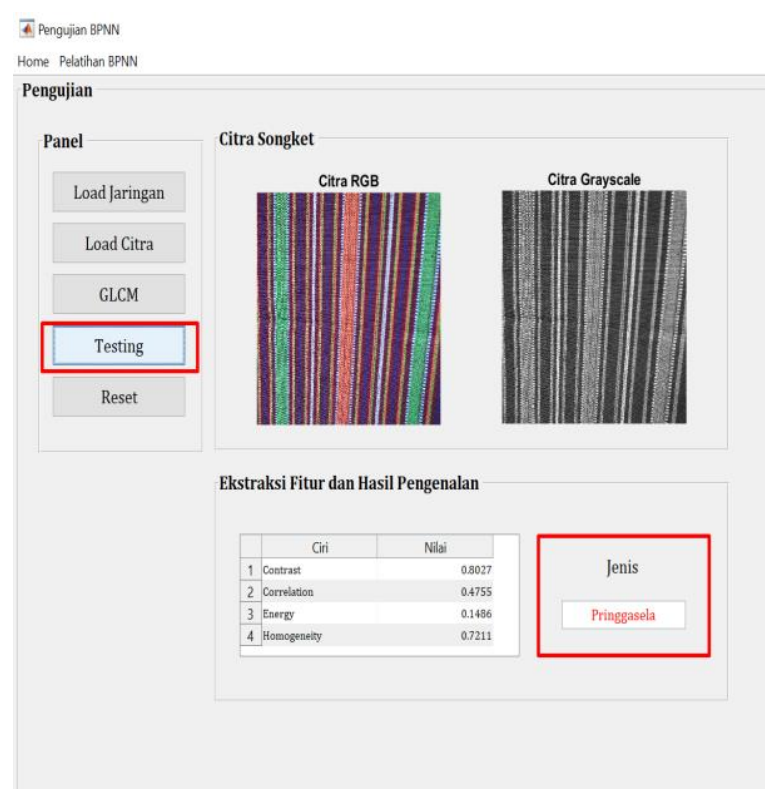

Source: (Imran \& Efendi, 2020)

Figure 3. The Implementation of Back-propagation Artificial Neural Network

In Figure 5 it can be seen the results of the classification using the Back-propagation Neural 
Network. In the picture before doing the application, first, the image of the songket cloth must be extracted using GLCM, after that there is button testing to perform classification.

\section{RESULTS AND DISCUSSIONS}

\section{A. The Implementation of GLCM}

The implementation of GLCM was carried out to obtain the extraction value on the songket cloth which was used as the object. The features used are Correlation, Contrast, Homogeneity and Energy, while the angle used is angle $0^{0}$. Table 1 is the extraction result from the image of the songket cloth used.

Table 1. Catudaya Component Functions

\begin{tabular}{|c|c|c|}
\hline Nama Songket & Fitur GLCM & Value \\
\hline \multirow[t]{4}{*}{ Anteng } & Correlation & 0.9767 \\
\hline & Homogeneity & 0.16011 \\
\hline & Energy & 0.00039 \\
\hline & Contrast & 118.824 \\
\hline \multirow[t]{4}{*}{ Sempara Jarang } & Correlation & 0.86613 \\
\hline & Homogeneity & 0.06916 \\
\hline & Energy & 0.00012 \\
\hline & Contrast & 1025.64 \\
\hline \multirow[t]{4}{*}{ Biru Garis } & Correlation & 0.75045 \\
\hline & Homogeneity & 0.04034 \\
\hline & Energy & 0.00015 \\
\hline & Contrast & 1282.45 \\
\hline \multirow[t]{4}{*}{ Antik } & Correlation & 0.77972 \\
\hline & Homogeneity & 0.04317 \\
\hline & Energy & 4.66425 \\
\hline & Contrast & 1532.45 \\
\hline \multirow{4}{*}{ Keker Sukarara } & Correlation & 0.93192 \\
\hline & Homogeneity & 0.18549 \\
\hline & Energy & 0.00151 \\
\hline & Contrast & 732.611 \\
\hline \multirow[t]{4}{*}{ Subhanale Sukarara } & Correlation & 0.89347 \\
\hline & Homogeneity & 0.09672 \\
\hline & Energy & 0.00018 \\
\hline & Contrast & 426.138 \\
\hline \multirow[t]{4}{*}{ Wayang } & Correlation & 0.88865 \\
\hline & Homogeneity & 0.08374 \\
\hline & Energy & 0.00024 \\
\hline & Contrast & 878.504 \\
\hline \multirow[t]{4}{*}{ Keker } & Correlation & 0.93956 \\
\hline & Homogeneity & 0.12565 \\
\hline & Energy & 0.00024 \\
\hline & Contrast & 376.127 \\
\hline \multirow[t]{4}{*}{ Pengginang } & Correlation & 0.94797 \\
\hline & Homogeneity & 0.15142 \\
\hline & Energy & 0.00022 \\
\hline & Contrast & 286.379 \\
\hline \multirow[t]{4}{*}{ Rarang } & Correlation & 0.7861 \\
\hline & Homogeneity & 0.1491 \\
\hline & Energy & 0.00036 \\
\hline & Contrast & 530.775 \\
\hline \multirow[t]{4}{*}{ Subhanale } & Correlation & 0.97522 \\
\hline & Homogeneity & 0.18829 \\
\hline & Energy & 0.00025 \\
\hline & Contrast & 87.9057 \\
\hline
\end{tabular}

Source: (Imran \& Efendi, 2020)

\section{B. The Implementation of JST Classification}

At this stage, the implementation of the Backpropagation Neural Network is carried out to classify the songket cloth used as an object. In the application used, Back-propagation JST performs a classification based on the results of the extraction using GLCM. At this stage, two stages will be carried out. Those are the training stage and the trial phase and using neurons 80 and 100 . Figure 4 shows the training process using Epoch 41 iterations with a time of 0:00:04.

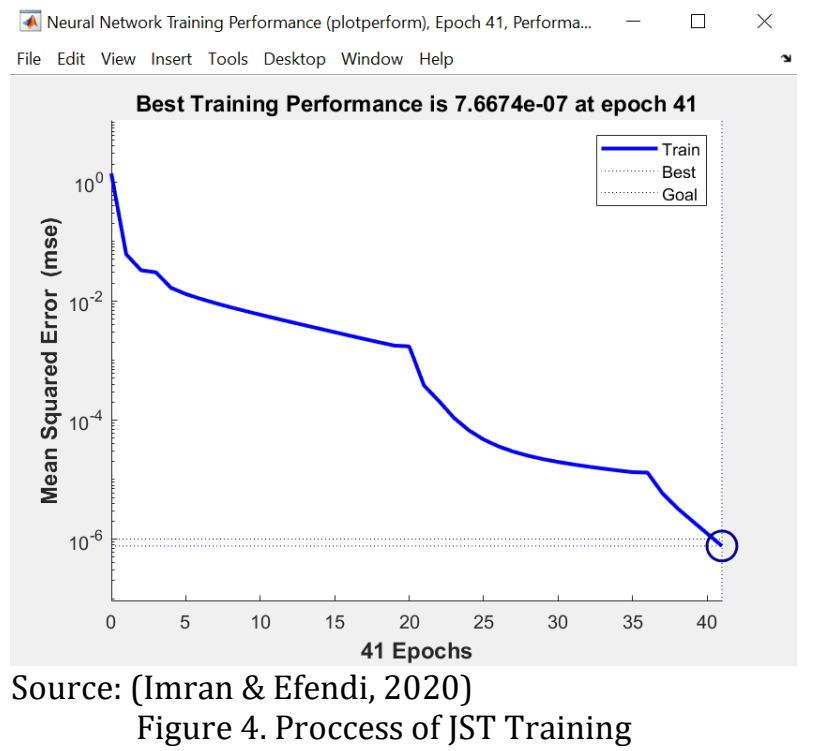

Whereas in Figure 5 is a graph of the process of back-propagation JST classification trials carried out, the data used at this trial stage are 11 pictures of songket cloth.

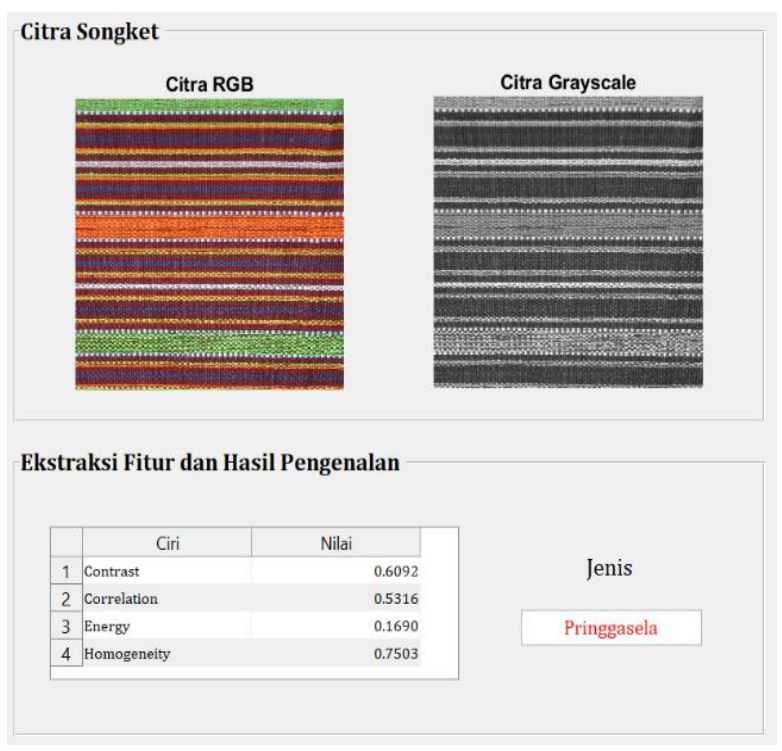

Source: (Imran \& Efendi, 2020)

Figure 5. Proccess classification

Table 2 is the result of the classification of trials conducted using neurons 80 . 
Table 2. JST Classification neuron 80

\begin{tabular}{ll}
\hline Songket Name & JST Classification Results \\
\hline Anteng & Succeed \\
\hline Sempara Jarang & Failed \\
\hline Biru Garis & Succeed \\
\hline Antik & Failed \\
\hline Keker Sukarara & Failed \\
\hline Subhanale Sukarara & Failed \\
\hline Wayang & Failed \\
\hline Keker & Failed \\
\hline Pengginang & Failed \\
\hline Rarang & Failed \\
\hline Subhanale & Failed \\
\hline Source: (Imran \& Efendi, 2020)
\end{tabular}

Whereas in Table 3 shows the results of trials using 100 neurons.

Table 3. JST classification neuron 100

\begin{tabular}{ll}
\hline \multicolumn{1}{c}{ Songket Name } & SST Classification Results \\
\hline Anteng & Succeed \\
\hline Sempara Jarang & Succeed \\
\hline Biru Garis & Succeed \\
\hline Antik & Succeed \\
\hline Keker Sukarara & Succeed \\
\hline Subhanale Sukarara & Succeed \\
\hline Wayang & Succeed \\
\hline Keker & Succeed \\
\hline Pengginang & Succeed \\
\hline Rarang & Succeed \\
\hline Subhanale & Succeed \\
\hline Source: (Imran \& Efendi, 2020)
\end{tabular}

\section{CONCLUSION}

In this study, 64 training data were used in the form of songket images taken from the pringgasela, sade and Sukarara areas. The test data used in this study were 11 data in the form of images of songket cloth. In the extraction process, GLCM uses angle 00 and uses 4 features, namely Correlation, Energy, Contrast and Homogeneity. In the classification stage using Artificial Neural Networks, the epoch used is 41 iterations with a time of 0:00:04, with neurons 80 and 100. After going through the classification stage using neurons 80 , from the test data used were 11 test data, resulting in $18 \%$ that were successfully classified. While using neuron 100, from the test data used as many as 11 test data, getting 100\% success can be classified. Based on the classification results that are obtained from the study, it can be concluded that the use of neurons 100 gets good classification results.

\section{REFERENCE}

A. Kasim, A., \& Harjoko, A. (2014). Klasifikasi Citra Batik Menggunakan Jaringan Syaraf Tiruan Berdasarkan Gray Level Co-Occurrence Matrices (GLCM). Seminar Nasional Aplikasi Teknologi Informasi, 1(1), 7-13. https://journal.uii.ac.id/Snati/article/view/3 256

Amalia, I. (2018). Ekstraksi Fitur Citra Songket Berdasarkan Tekstur Menggunakan Metode Gray Level Co-occurrence Matrix (GLCM). Jurnal Infomedia, 3(2), 64-68.

Gressiva., and Chandra, F. (2018). Sistem Pengenalan Motif Songket Melayu Menggunakan Ekstraksi Fitur Principal Component Analysisdan Gray Level CoOccurence Matrix dan Jaringan Saraf Tiruan. Jom FTEKNIK, 5(2), 1-7. https://jom.unri.ac.id/index.php/JOMFTEKN IK/article/view/22206

Imran, B. (2019). Content-Based Image Retrieval Based on Texture and Color Combinations Using Tamura Texture Features and Gabor Texture Methods. American Journal of Neural Networks and Applications. American Journal of Neural Networks and Applications, 5(1), 23-27.

Imran, B., \& Efendi, M. M. (2020). Laporan Penelitian Akhir Mandiri: The Implementation Of Extraction Feature Using Glcm And BackPropagation Artificial Neural Network To Clasify Lombok Songket Woven Cloth.

Imran, B., Gunawan, K., Zohri, M., \& Bakti, L. D. (2018). Fingerprint Pattern of Matching Family with GLCM Feature. Telkomnika, 16(4), 1864-1869.

Mauko, I, C., and Lukmetlabla, N, M, S. (2016). Pengenalan pola citra digital motif kain tenun alor menggunakan metode transformasi wavelet dan adaptive neuro-fuzzy Inference system. Seminar Nasional Sainstek, 51-57.

Mohanaiah, P., Sathyanarayana, P., \& GuruKumar, L. (2013). Image texture feature extraction using GLCM approach. International Journal of Scientific and Research Publications, 3(5), 290-294. http://www.ijsrp.org/researchpaper-0513/ijsrp-p1750.pdf

Pathak, B., \& Barooah, D. (2013). Texture analysis based on the gray-level co-occurrence matrix 
considering possible orientations. International Journal of Advanced Research in Electrical, Electronics and Instrumentation Engineering. Electronics and Instrumentation Engineering, 2(9), 4206-4212.

Sari, Y. (2018). Klasifikasi Pengenalan Motif Batik Berbasis Image Retrival. Jurnal Teknik Lingkungan, 4(2), 27-33. https://ppjp.ulm.ac.id/journal/index.php/juk ung/article/view/6581

Setiohardjo, N. M. (2013). Texture Analysis for Fabric Motif Classification (Case Study: Nusa Tenggara Timur Woven Fabric). Indonesian Journal of Computing and Cybernetics Systems, 8(2), 177-188.

Soesanti, I. (2015). Klasifikasi dan pengenalan pola batik berbasis ciri statistis. CITEE 2015, 304309.

http://citee.ft.ugm.ac.id/2015/proceeding/d ownload51.php?f=Indah Soesanti - Klasifikasi dan Pengenalan Pola.pdf

Suharjito, S., Imran, B., \& Girsang, A. S. (2017). Family Relationship Identification by Using Extract Feature of Gray Level Co-occurrence Matrix (GLCM) Based on Parents and Children Fingerprint. International Journal of Electrical and Computer Engineering (IJECE), $7(5)$, 2738-2745. https://doi.org/10.11591/ijece.v7i5

Surya, R. A., Fadlil, A., \& Yudhana, A. (2017). Ekstraksi Ciri Metode Gray Level CoOccurrence Matrix (GLCM) dan Filter Gabor untuk Klasifikasi citra Batik Pekalongan. Jurnal Informatika: Jurnal Pengembangan IT, 2(2), 23-26. 